\title{
Direct Determination of Cadmium in Uranium-Zirconium-based Metallic Fuel Using GFAAS: An Insight Into the Effect of Matrix on the Atomization of Cadmium
}

\author{
S.K. Thulasidas*, Santosh Kumar Gupta, and V. Natarajan \\ Radiochemistry Division, Bhabha Atomic Research Centre \\ Trombay, Mumbai 400 085, India
}

\section{INTRODUCTION}

Uranium- and plutonium-based nuclear fuels are required to conform to stringent specifications as regards the trace metallic constituents since they have an important bearing on fuel performance. Trace metals, such as B, Cd, and Gd in particular amongst the rare earths, have a very high neutron absorption cross-section which in turn can affect the neutron economy of the reactor fuel $(1,2)$. Cadmium is one such element to be monitored in the fuel. It has a high neutron absorption cross-section (2275 barns). The determination of impurities in uranium and zirconium at the various stages of the nuclear fuel cycle plays an important role in quality control and in the achievement of chemical and metallurgical requirements.

A number of analytical methodologies have been used for the elemental characterization of fuels depending on the target analytes and concentration range of the impurities, required precision, sample throughput, and time of analysis. These methods include inductively coupled plasma mass spectrometry (ICP-MS), inductively coupled plasma atomic emission spectrometry (ICP-AES), and graphite furnace atomic absorption spectrometry (GFAAS).

Atomic absorption spectrometry (AAS) is one of the important techniques used in all analytical labora-

Corresponding autbor.

E-mail: tulsidas@barc.gov.in

\section{ABSTRACT}

In the present work, the atomization of $\mathrm{Cd}$ in a complex matrix $(\mathrm{U}+\mathrm{Zr})$, the matrix effects of the $\mathrm{Zr} / \mathrm{U}+\mathrm{Zr}$ composition, and the matrix concentration of $\mathrm{U}+\mathrm{Zr}$ are studied. It was found that the matrix composition was finalized to $20 \% \mathrm{Zr} / \mathrm{U}+\mathrm{Zr}$ and the total matrix $(\mathrm{U}+\mathrm{Zr}$ ) concentration finalized as $20 \mathrm{mg} / \mathrm{mL}$ using graphite furnace atomic absorption spectrometry (GFAAS). The range of analysis was found to be $0.005-0.08 \mu \mathrm{g} / \mathrm{mL}$ for Cd with a $20 \mathrm{mg} / \mathrm{mL}$ matrix, resulting in detection limits of $0.005 \mu \mathrm{g} / \mathrm{mL}$ (i.e., $0.25 \mathrm{ppm}$ ). The performance of the method was validated by analyzing synthetic samples with a $\mathrm{U}+\mathrm{Zr}$ matrix. The values obtained for the synthetic samples agreed favorably with the added concentrations. It is of significance to note that the present method gains in importance due to its ability to determine $\mathrm{Cd}$ without the need for a prior chemical separation of the $\mathrm{U}+\mathrm{Zr}$ matrix. The analytical procedure developed could not be applied directly to the analyses of Fast Breeder Reactor sample solutions due to stringent limits. However, matrix separation by the chemical method enables GFAAS analysis to estimate $\mathrm{Cd}$ at the required level of $0.1 \mathrm{ppm}$. The suppression in absorbance in the presence of the matrix was correlated with the atomization mechanism which was based on the activation energy calculation using the Arrhenius plots. tories working on trace metallic assay of various materials. The strong point in favor of AAS, in particular with an electrothermal atomizer (ETA), is its ability to provide precise results and high sensitivity, and measurements in only a significantly small sample size. In GFAAS, the atomizer suffers physical and chemical interferences, which includes loss of volatile elements like $\mathrm{Cd}$. These types of studies with matrix interference on the Cd signal are performed for beryllium (2) and arsenic samples (3) in our laboratories. However, only a few of our reports have been published from our laboratory on atomic spectroscopic methods for the determination of cadmium in uranium (4-6) and zirconium (7).

Reports are available in the literature for the flame and flameless AAS determination of cadmium in water samples (8-10), high purity iron (11), fish (12), plant (13), tea (14), serum (15), high purity materials (16), milk $(17,18)$, oil (19), blood (20), food (21-23), biological materials (24), environmental samples (25), and soil samples $(26,27)$.

In addition to AAS, other analytical techniques are also in use for the determination of cadmium in food samples by adsorptive stripping voltammetry (28), blood by ICP-MS (29), different environmental water samples with dispersive liquid-liquid microextraction preconcentration combined with ICPAES (30), and in environmental and biological samples with phase transfer hollow fiber liquid phase microextraction combined with electrothermal vaporization ICP-MS 
(31). Earlier, Huff et al. (32) attempted to determine the trace metal impurities in U-Pu-Zr alloy fuel using anion exchange partition chromatography. While there is a fairly diverse array of data on the behavior of plutonium (33), thorium (34), uranium (4-6), zirconium (7), and the determination of silver in zirconium-uranium matrices (35), no studies of a combined $\mathrm{U}+\mathrm{Zr}$ system on $\mathrm{Cd}$ have been published using the AAS techniques.

The present work focuses mainly on establishing the effect of a $\mathrm{U}+\mathrm{Zr}$ matrix on the absorbance of Cd. Studies with the change in the analyte absorbance signals and the change in matrix composition $\% \mathrm{Zr} / \mathrm{U}+\mathrm{Zr}$ and matrix concentration of $\mathrm{U}+\mathrm{Zr}$ in GFAAS have helped in the optimization of the method. The suppression was reported with an individual $\mathrm{Zr}$ matrix (7) and $\mathrm{U}$ matrix (4-6). The absorbance remained more or less constant with a change in $\% \mathrm{Zr}$ in the $\mathrm{U}+\mathrm{Zr}$ matrix. A marginal suppression in Cd absorbance was observed in the $\mathrm{U}+\mathrm{Zr}$ matrix as compared to the pure uranium matrix but a large suppression in Cd absorbance with respect to the matrix-free solution. A comparison of the $\mathrm{Cd}$ atom density in pure and in matrix oxides was used to understand the matrix effect on the Cd absorbance signal. These studies were then utilized for the direct determination of $\mathrm{Cd}$ at $0.005 \mu \mathrm{g} / \mathrm{mL}$ in the $\mathrm{U}+\mathrm{Zr}$ matrix with $20 \% \mathrm{Zr}$ in a $20-\mathrm{mg} / \mathrm{mL} \mathrm{U}+\mathrm{Zr}$ matrix solution. The range of analysis was found to be $0.005-0.08$ $\mu \mathrm{g} / \mathrm{mL}$ for Cd with a $20 \mathrm{mg} / \mathrm{mL}$ matrix, which leads to detection limits of $0.25 \mathrm{ppm}$. The performance of the method was evaluated by analyzing synthetic samples of $\mathrm{U}+\mathrm{Zr}$.

\section{EXPERIMENTAL}

\section{Instrumentation}

A computer-controlled GBC-906 atomic absorption spectrometer (GBC Scientific Equipment, Australia), equipped with a GF 3000 graphite furnace atomizer, was used for the determination of Cd. Details of the AAS instrument are reported earlier (35). The atomizer was covered with a shield made of Perspex ${ }^{\circledR}$ which could be removed when access to the atomizer was necessary. Containment of the uranium-zirconium fumes was ensured through an adequate exhaust system provided around the atomizer. The atomizer unit exhaust was connected to a glove box exhaust system (Figure 1).

\section{Standard Solutions}

The preparation of $\mathrm{U}$ and $\mathrm{Zr}$ matrix solutions was reported by our laboratory for uranium (200 $\mathrm{mg} / \mathrm{mL}$ ) and zirconium $(14 \mathrm{mg} / \mathrm{mL})$ solutions (35). A cadmium working solution was prepared by appropriate dilution of standard stock solutions $(\mathrm{Cd} 1 \mathrm{mg} / \mathrm{mL}$ in 5\% nitric acid; VHG Labs.). To study the matrix composition effect, a midrange concentration standard was prepared for Cd with varying amounts of $\mathrm{Zr}$ in a $\mathrm{U}+\mathrm{Zr}$ matrix ranging from $0-40 \%$ (zero concentration corresponds to $20 \mathrm{mg} / \mathrm{mL}$ U alone). To study the matrix concentration effect, a standard of midrange concentration was prepared with varying amounts of matrix ranging from $0-40 \mathrm{mg} / \mathrm{mL}$. After optimizing the matrix proportion, a series of standard solutions was prepared with and without matrix [ $4 \mathrm{mg} / \mathrm{mL} \mathrm{Zr}, 16 \mathrm{mg} / \mathrm{mL} \mathrm{U}$, and $20 \mathrm{mg} / \mathrm{mL} 20 \% \mathrm{Zr}+\mathrm{U}$ ( $4 \mathrm{mg} / \mathrm{mL} \mathrm{Zr}+$ $16 \mathrm{mg} / \mathrm{mL} \mathrm{U}$ )] matrix and graded concentrations of $\mathrm{Cd}$ in the range of $0-100 \mathrm{ng} / \mathrm{mL}$. In the absence of certified reference materials with this matrix, three synthetic samples of $(\mathrm{U}+\mathrm{Zr})$ were prepared with a matrix of $20 \mathrm{mg} / \mathrm{mL} 20 \% \mathrm{Zr}+\mathrm{U}$ (i.e., $4 \mathrm{mg} / \mathrm{mL} \mathrm{Zr}+16 \mathrm{mg} / \mathrm{mL} \mathrm{U}$ ) and graded concentrations of $\mathrm{Cd}$ at $0.016,0.03$, and $0.05 \mu \mathrm{g} / \mathrm{mL}$ which is equivalent to $0.8,1.5$, and 2.5 $\mathrm{ppm}(\mu \mathrm{g} / \mathrm{g})$ in a $20 \mathrm{mg} / \mathrm{mL} \mathrm{Zr}+\mathrm{U}$ matrix.

\section{Instrumental Parameters}

The instrumental parameters used for Cd are given in Table I. Argon gas of purity 99.995 vol. \% was used as a purge gas.

The fundamental conditions of GFAAS analysis (such as temperature and time durations at pre-atomization and atomization steps) were investigated in order to identify the

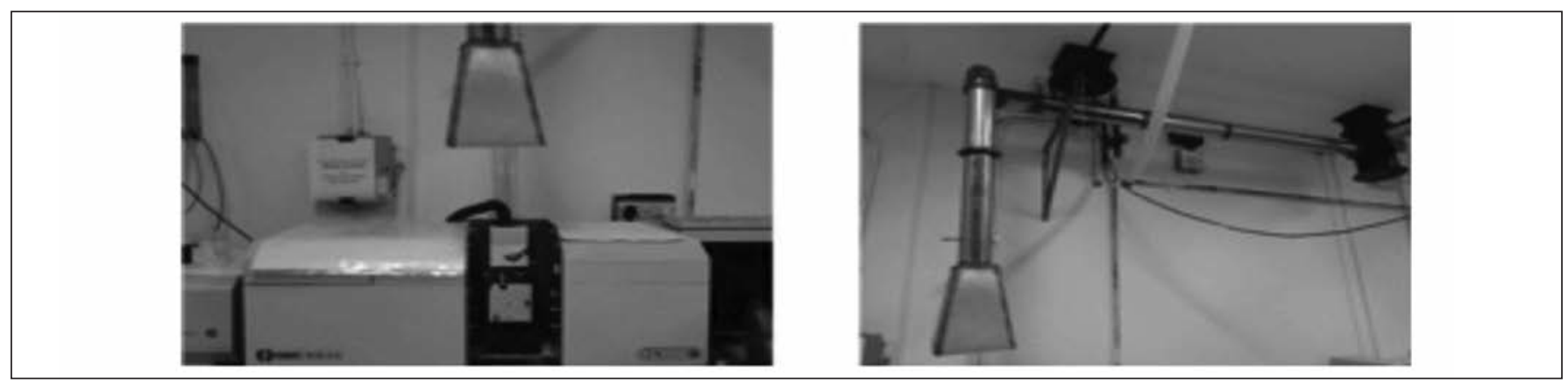

Fig. 1. Schematic of atomizer with glove box exhaust system. 
optimum conditions for obtaining stable and sensitive atomic absorbance signals for $\mathrm{Cd}$ with and without matrix. The detailed procedure adopted here was similar to that followed earlier for trace metal analysis of $\mathrm{Cd}$ in a $\mathrm{BeO}$ matrix (2). A Model M/s Raytek ${ }^{\circledR}$ two-color optical pyrometer (Raytek, USA), sensitive in the range of 1000-3000 ${ }^{\circ} \mathrm{C}$, was used to measure the temperatures in the atomization stage. Cd absorbance was monitored as a function of (a) matrix composition on a fixed concentration of $\mathrm{Cd}$ and varying zirconium proportions in the range $0-40 \% \mathrm{Zr}$ and (b) matrix concentration in the range $0-40$ $\mathrm{mg} / \mathrm{mL}$ of $\mathrm{U}+\mathrm{Zr}$ using fixed analyte concentrations. The characteristic concentration was obtained for $\mathrm{Cd}$ by analyzing three sets of standards, i.e., one each in $4 \mathrm{mg} / \mathrm{mL} \mathrm{Zr}$, $16 \mathrm{mg} / \mathrm{mL} \mathrm{U}, 20 \mathrm{mg} / \mathrm{mL} \mathrm{U}+20 \% \mathrm{Zr}$, and without matrix with a graded proportion of $\mathrm{Cd}$.

The study on the atomization of $\mathrm{Cd}$ in a matrix-free solution as well as in a $\mathrm{U}+\mathrm{Zr}$ matrix has resulted in the optimization of the analytical procedure for the analysis of the $\mathrm{Cd} / \mathrm{U}+\mathrm{Zr}$ matrix.

The atomization mechanism for Cd atomization was studied using the absorbance-time-temperature profile of the absorbance signal. From the initial portion of the profile at various temperature points, corresponding absorbance signals were measured. From these data

TABLE I

Instrumental Parameters for Cd With GF-3000 AAS

\begin{tabular}{ll}
\hline Wavelength & $228.1 \mathrm{~nm}$ \\
Spectral Bandwidth & $0.5 \mathrm{~nm}$ \\
Lamp Fill Gas & $\mathrm{Ne}$ \\
Lamp Current & $5 \mathrm{~mA}$ \\
Gas Used & $\mathrm{Ar}$ \\
Flow Rate $^{\text {a }}$ & $6 \mathrm{~L} / \mathrm{min}$ \\
\hline
\end{tabular}

\footnotetext{
a Only during 'dry' and 'pre-atomization' stage.
}

points, the Arrhenius plot of $\log$ absorbance vs. inverse of absolute temperature was obtained and used to calculate the activation energies $\left(\mathrm{E}_{\mathrm{a}}\right)$; signal appearance temperatures $\left(\mathrm{T}_{\mathrm{app}}\right)$ were obtained from the absorbance profile for matrix and matrix-free solutions. The appearance temperature is the temperature producing a just noticeable signal above the blank absorbance.

\section{Separation of Major Matrix}

To utilize the separated samples from the matrix for the determination of $\mathrm{Cd}$, a mid-range concentration at $0.04 \mu \mathrm{g} / \mathrm{mL}$ standard was prepared for $\mathrm{Cd}$ in a $20 \% \mathrm{Zr} / \mathrm{U}+\mathrm{Zr}$ matrix at $1 \mathrm{~g} / \mathrm{mL}$ solution. For quantitative chemical separation of the analytes, 30\% TBP/dodecane in $7 \mathrm{M}$ $\mathrm{HNO}_{3}$ was used. To utilize the separated method for the determination of the analyte, it is important to understand the effect of $\mathrm{U}+\mathrm{Zr}$ in raffinate solution on the $\mathrm{Cd}$ absorbance. Therefore, to study the matrix effect in a raffinate solution, a Cd $(0.04 \mu \mathrm{g} / \mathrm{mL})$ standard was prepared with varying amounts each of $20 \% \mathrm{Zr} / \mathrm{U}+\mathrm{Zr}$ matrix at much lower matrix concentrations (in the range $10-50 \mu \mathrm{g} / \mathrm{mL}$ ).

\section{RESULTS AND DISCUSSION}

In GFAAS, atomization of an analyte in the presence of a complex matrix such as $\mathrm{Pu}, \mathrm{U}, \mathrm{Zr}$, and $\mathrm{Th}$ is the result of an interaction of analyte matrix, analyte-carbon, or carbon matrix (34). Earlier we carried out investigations in matrices such as $\mathrm{U}$ (5), $\mathrm{Th}$ (36), $\mathrm{Zr}(7)$, and $\mathrm{U}+\mathrm{Pu}$ (37) on the absorbance and atomization behavior of $\mathrm{Cd}$. Inference drawn from these studies shows that the absorbance of $\mathrm{Cd}$ is found to be different in the matrix compared to a matrix-free solution. These results propelled us to investigate similar studies in $\mathrm{U}+\mathrm{Zr}$, a fuel proposed for fast breeder reactors. The atomization behavior of $\mathrm{Cd}$ was, therefore, studied to under- stand the effect of $\mathrm{Zr}, \mathrm{U}$, and $\mathrm{U}+\mathrm{Zr}$ by measuring the atomic absorption signal for $\mathrm{Cd}$ with and without a matrix.

The experimental parameters such as pre-atomization and atomization temperatures were optimized for Cd in matrix-free solutions. The effect of pre-atomization was investigated on the absorbance of $\mathrm{Cd}$ in the temperature range of 200 to $500{ }^{\circ} \mathrm{C}$. The temperature is critical in the case of Cd because $\mathrm{Cd}\left(\mathrm{NO}_{3}\right)_{2}$ decomposes at $334^{\circ} \mathrm{C}$ to oxide $(\mathrm{CdO})$, which boils at $\mathrm{T}_{\mathrm{bo}}=765^{\circ} \mathrm{C}$ and hence, the possibility of pre-atomization losses are high for the analyte at high temperatures (38). The optimized temperature was $300{ }^{\circ} \mathrm{C}$ for pre-atomization of the analyte. Studies on the atomization behavior in the temperature range of 1900 to $2700{ }^{\circ} \mathrm{C}$ showed that the optimum temperature for atomization was $2300{ }^{\circ} \mathrm{C}$. A similar optimization studied in the presence of a uranium matrix was found to be 500 and $2300{ }^{\circ} \mathrm{C}$ for pre-atomization and atomization, respectively.

\section{Effect of Matrix Composition}

Using the optimized uranium matrix parameters, the effect of matrix composition was studied by varying the $\mathrm{Zr}$ percentage in the $\mathrm{U}+\mathrm{Zr}$ matrix from $0-40 \%$, keeping the total matrix concentration as $20 \mathrm{mg} / \mathrm{mL}$ at $0.04 \mu \mathrm{g} / \mathrm{mL}$ of $\mathrm{Cd}$. The results indicated that the $\mathrm{Cd}$ absorbance signal remained unaffected in the range of $0-40 \% \mathrm{Zr}$ in the $(\mathrm{U}+\mathrm{Zr})$ mixed matrix with $20 \mathrm{mg} / \mathrm{mL}$ total matrix. As can be seen from Table II, the absorbance remains essentially the same irrespective of the data collected from $0-40 \%$ or $40-0 \% \mathrm{Zr}$ on a new graphite atomizer each time, unlike $\mathrm{Ag}$ in the $\mathrm{U}+\mathrm{Zr}$ matrix (35).

This probably can be explained on the basis of the effect of uranium and zirconium matrices on $\mathrm{Cd}$ and $\mathrm{Ag}$ absorbance. In the pres- 
ence of $20 \mathrm{mg} / \mathrm{mL}$ of $U$ matrix, the Cd (5) and Ag (39) absorbance of both analytes is suppressed enormously, while at $10 \mathrm{mg} / \mathrm{mL} \mathrm{Zr}$ matrix the Cd absorbance suppressed to $50 \%$ (7) and did not change the absorbance of Ag (40). The presence of a combined matrix $(\mathrm{U}+\mathrm{Zr})$ did not change the absorbance of $\mathrm{Cd}$ with a change of $\mathrm{Zr}$ at $0-40 \%$ concentration in the $\mathrm{U}+\mathrm{Zr}$ matrix. It also remained the same when the $\mathrm{Zr}$ content is changed from $40-0 \% / \mathrm{U}+\mathrm{Zr}$ matrix. This means that the $\mathrm{Cd}$ absorbance remained the same every time when studies were carried out with a $0-40 \%$ or $40-0 \% \mathrm{Zr} / \mathrm{U}+\mathrm{Zr}$ matrix on a new atomizer. However, the presence of the $\mathrm{Zr}$ matrix does not show any suppression for Ag (40) and hence, studies in which the percentage of $\mathrm{Zr}$ was increased and decreased were found to be affected differently.

\section{Effect of Matrix Concentration}

A study on the atomization of $\mathrm{Cd}$ in a mixed matrix was carried out with varying concentrations of the matrix $(0-40 \mathrm{mg} / \mathrm{mL})$. The variation obtained in absorbance signal as a function of matrix concentration is shown in Figure 2. As can be seen from the data, a suppression in the absorbance signal was observed with an increase in matrix concentration up to $40 \mathrm{mg} / \mathrm{mL}$. With an increase in concentration, the variation in Cd absorbance is not much (from 5-20 mg/mL) and a higher matrix concentration is always pre- ferred as it provides better detection limits. Therefore, for further studies, a $20 \mathrm{mg} / \mathrm{mL}$ concentration was used.

\section{Zr, U, and U+Zr Matrix Effect}

$20 \mathrm{mg} / \mathrm{mL}$ of $20 \% \mathrm{Zr}$ in $\mathrm{U}+\mathrm{Zr}$ matrix contains $16 \mathrm{mg} / \mathrm{mL} \mathrm{U}$ and $4 \mathrm{mg} / \mathrm{mL} \mathrm{Zr}$. So, the effect of individual matrixes was also studied. It was observed that in the presence of $16 \mathrm{mg} / \mathrm{mL} \mathrm{U}$ matrix, the absorbance signal for Cd was reduced to $\sim 40 \%$ in comparison to that observed in matrix-free solution. It was observed that in the presence of $4 \mathrm{mg} / \mathrm{mL} \mathrm{Zr}$ matrix, the absorbance signal for Cd was reduced to $\sim 50 \%$ in comparison to that observed in a matrix-free solution.

To understand the suppression of Cd absorbance in the presence of the matrix, the reaction mechanism involved in the atomization of $\mathrm{Cd}$ in the presence and absence of the matrix was studied using the Arrehenius plots of $\ln (\mathrm{A})$ vs. $\mathrm{T}^{-1}$.

The studies so far reported in the literature are all carried out on analytes with water or weak acids (41). The nature of the reaction mechanism gets significantly altered when atomization of the analytes in the presence of complex matrices such as $U$ and $\mathrm{U}+\mathrm{Zr}$ takes place. The present data deals with the study of the reaction mechanism involved in the atomization of Cd from $\mathrm{U}$ and $\mathrm{U}+\mathrm{Zr}$ matrices. Activation energy $\left(\mathrm{E}_{\mathrm{a}}\right)$ values were calculated from the Arrhenius plot in a similar manner as reported earlier (41). The plot of $\log$ absorbance as a function of inverse of the absolute temperature should yield one or more straight lines with slope $=-\mathrm{E}_{\mathrm{a}} / 2.303 \mathrm{R}$, where $\mathrm{R}$ represents the gas constant.

Since construction of a $\log$ absorbance versus 1/T plot requires that the temperature of the atomic vapor be equal to that of the surface of the furnace, absorbance measurements for $\mathrm{E}_{\mathrm{a}}$ value calculations were restricted to the initial few hundred milliseconds of the absorption profile (see Figure 3, Absorbance - Time profile). Absorbance data taken from this region of the curve were used to construct the $\mathrm{E}_{\mathrm{a}}$ plots.

The $\mathrm{E}_{\mathrm{a}}$ plots were obtained in the presence of matrices for $\mathrm{Cd}$. Signals $\mathrm{T}_{\mathrm{app}}$ and $\mathrm{E}_{\mathrm{a}}$ were found to be the same in both the aqueous and (U, Zr) matrix, i.e., independent of the matrix. The values are listed in Table III.

To support our findings of the $\mathrm{E}_{\mathrm{a}}$ value, the thermodynamic data were taken from the literature (41) for comparison. The dissociation energy values obtained in our studies were $294 \mathrm{kj} / \mathrm{mol}$ and $315 \mathrm{kj} / \mathrm{mol}$

TABLE II

Absorbance Signal With $\mathrm{Zr} / \mathrm{Zr}+\mathrm{U}$ Ratio Decreasing and Absorbance Signal With $\mathrm{Zr} / \mathrm{Zr}+\mathrm{U}$ Ratio Increasing

\begin{tabular}{ccc|rrc}
\hline $\begin{array}{c}\mathrm{Zr} \% \\
\text { Decreasing on } 0.08 \mu \mathrm{g} / \mathrm{mL} \mathrm{Cd}\end{array}$ & \multicolumn{4}{|c}{$\mathrm{Zr} \%$ Increasing on } & $0.08 \mu \mathrm{g} / \mathrm{mL} \mathrm{Cd}$ \\
& Absorbance & $\mathrm{Zr}$ & $\% \mathrm{U}$ & Absorbance \\
\hline 40 & 60 & 0.286 & 0 & 100 & 0.224 \\
20 & 80 & 0.282 & 5 & 95 & 0.211 \\
10 & 90 & 0.292 & 10 & 90 & 0.255 \\
5 & 95 & 0.248 & 20 & 80 & 0.301 \\
0 & 100 & 0.274 & 40 & 60 & 0.301 \\
\hline
\end{tabular}

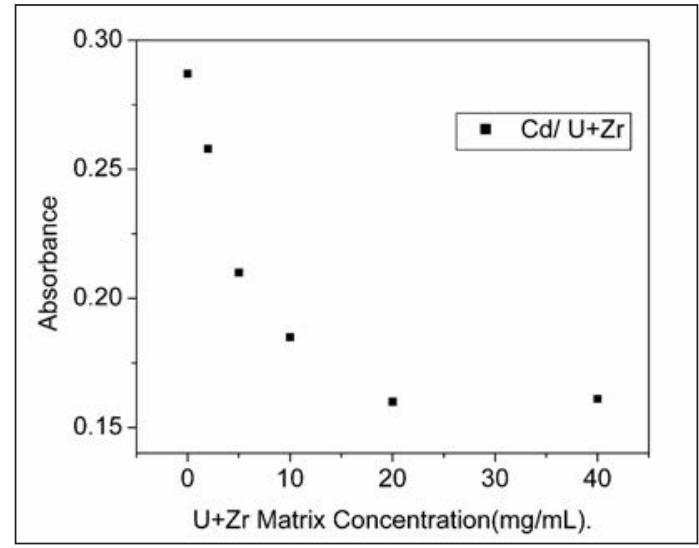

Fig. 2. Matrix concentration; effect on $0.08 \mu \mathrm{g} / \mathrm{mL} \mathrm{Cd}$. 
for cadmium oxide in a matrix-free and $\mathrm{U}+\mathrm{Zr}$ matrix, respectively, and these are rather close to correspondingly reported (41) values $(\mathrm{CdO}=340 \mathrm{kj} / \mathrm{mol})$. In the present studies, therefore, it was concluded that dissociation of the oxide is the only mode of atomization for $\mathrm{Cd}$. From the $\mathrm{E}_{\mathrm{a}}$ energy values, we can infer that most probably the species available prior to $\mathrm{T}_{\text {app }}$ are $\mathrm{CdO}(\mathrm{s})$ and therefore the sequence of atomization suggested is as follows:

$\mathrm{Cd}\left(\mathrm{NO}_{3}\right)_{2} \cdot 4 \mathrm{H}_{2} \mathrm{O} \rightarrow \mathrm{CdO}(\mathrm{s}) \rightarrow \mathrm{Cd}_{(\mathrm{g})}$

Having obtained a value of $\mathrm{E}_{\mathrm{a}}$ and a possible atomization sequence, it is necessary to ensure that the resulting intermediate satisfies physical constants. Here, from the $\mathrm{E}_{\mathrm{a}}$ data, the oxide in solid state was the precursor to the gaseous atoms. At $\mathrm{T}_{\text {app }}$ the $\mathrm{CdO}(\mathrm{s})$ was in solid state (melting point $-\mathrm{CdO}(\mathrm{s})=1173^{\circ} \mathrm{C}$ ) and once dissociated, $\mathrm{Cd}$ goes to gaseous form directly (boiling point - $\mathrm{Cd}=334^{\circ} \mathrm{C}$ ).

The mode of atomization and possible intermediate reactions are useful in understanding the possible interference effects in case of complex matrices. It was observed that the slope of the calibration curves obtained for the aqueous medium was significantly altered when uranium, zirconium, and $\mathrm{U}+\mathrm{Zr}$ matrices were introduced, suggesting strong matrix influence on the atomization behavior of $\mathrm{Cd}$.

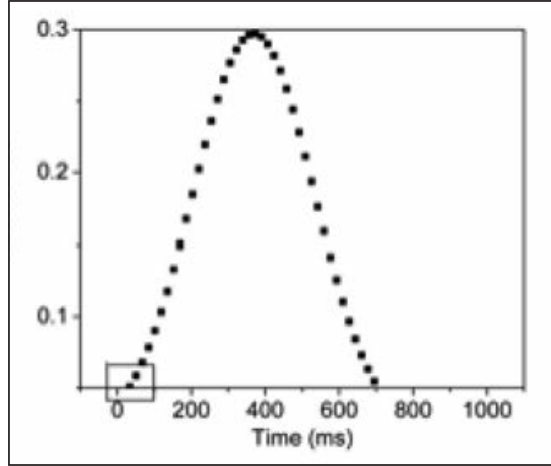

Fig. 3. Typical absorbance-time profile showing the part of the curve from which the data were taken.
Since signal appearance temperatures and $\mathrm{E}_{\mathrm{a}}$ values remained the same in the aqueous, $\mathrm{Zr}, \mathrm{U}$, and $\mathrm{U}+\mathrm{Zr}$ matrices, suppression of the absorbance in the presence of $\mathrm{Zr}$, $\mathrm{U}$, and $\mathrm{U}+\mathrm{Zr}$ matrices could not be explained from these studies.

GFAAS provides only indirect information of the atomization process of the analytes occurring in a graphite atomizer. We tried to explain the change in analyte atomization efficiency in the presence of the matrix with the dissociation of the analyte nitrates, uranyl nitrate/uranium+zirconium nitrate. Thermogravimetric analysis (42) shows the decomposition of uranyl nitrate to its dioxide in the temperature range of $297-1297^{\circ} \mathrm{C}$ and zirconium nitrate as follows:

$$
\begin{aligned}
& \mathrm{Cd}\left(\mathrm{NO}_{3}\right)_{2} \cdot 4 \mathrm{H}_{2} \mathrm{O} \rightarrow \mathrm{CdO}_{(\mathrm{s})} \\
& \mathrm{UO}_{2}\left(\mathrm{NO}_{3}\right)_{2} \cdot 6 \mathrm{H}_{2} \mathrm{O}_{(\mathrm{s})} \rightarrow \mathrm{UO}_{3(\mathrm{~s})} \rightarrow \\
& 1227^{\circ} \mathrm{C} \\
& \mathrm{U}_{3} \mathrm{O}_{8(\mathrm{~s})} \rightarrow \mathrm{UO}_{2(\mathrm{~s})} \\
& \quad 227^{\circ} \mathrm{C} \\
& \left.\mathrm{Zr}\left(\mathrm{NO}_{3}\right)_{4(\mathrm{~s})}\right) \rightarrow \mathrm{ZrO}_{2(\mathrm{~s})}
\end{aligned}
$$

Both uranium, zirconium, and $\mathrm{U}+\mathrm{Zr}$ nitrates get converted into their respective dioxides. Both $\mathrm{UO}_{2}$ and $\mathrm{ZrO}_{2}$ thus formed are very stable lattices. Similarly, the Cd also gets converted into the oxide, mostly dissolved in the main lattice of $\mathrm{UO}_{2}$ and $(\mathrm{U}+\mathrm{Zr}) \mathrm{O}_{2}$. The diffusion rates of the cationic elements in these lattices are very low (33). A small amount of the analyte dissolved in the $(\mathrm{U}, \mathrm{Zr}) \mathrm{O}_{2}$ lattice con-

\section{Atomic Apectroscopy 1 Vol. 35(4), July/August 2014}

siderably reduces the chemical activities, hence the detectability and suppression in absorbance in the presence of the matrix. $\mathrm{UO}_{2}$ and $\mathrm{ZrO}_{2}$ dissociate only above $3000{ }^{\circ} \mathrm{C}$, which is not attainable in the GF atomizer. Hence, the analytes remain trapped in the $\mathrm{UO}_{2}+\mathrm{ZrO}_{2}$ lattice, which explains the poor atomization efficiency.

Having finalized the percentage of $\mathrm{Zr}$ and the concentration of the matrix, the experimental parameters were again optimized with $20 \% \mathrm{Zr} / \mathrm{U}+\mathrm{Zr}$ at $20 \mathrm{mg} / \mathrm{mL}$ matrix. For optimization of the GFAAS measurement parameters, the effects of the pre-atomization and atomization temperature on the $\mathrm{Cd}$ absorbance were freshly investigated on the GF 3000. The results of the pre-atomization/atomization studies for uranium are shown in Table IV.

The optimized temperatures for pre- and atomization are finalized at 400 and $2300{ }^{\circ} \mathrm{C}$, respectively. The optimized experimental parameters with $5 \mu \mathrm{L} /$ loading of $20 \% \mathrm{Zr} / \mathrm{U}+\mathrm{Zr}$ at $20 \mathrm{mg} / \mathrm{mL}$ concentration are shown in Table V.

Successive loadings of $(\mathrm{U}+\mathrm{Zr}$ ) solution leads to matrix buildup inside the graphite atomizer. However, this buildup of matrix did not have any significant effect on the $\mathrm{Cd}(0.04 \mu \mathrm{g} / \mathrm{mL})$ absorbance with repetitive loading of the $20.0 \mathrm{mg} / \mathrm{mL}$ mixed matrix on the same atomizer. The absorbance remained con-

\begin{tabular}{|c|c|c|c|c|c|c|}
\hline \multirow{4}{*}{$\begin{array}{l}\text { Ele- } \\
\text { ment }\end{array}$} & \multicolumn{3}{|c|}{ Applied Temp. $\left({ }^{\circ} \mathrm{C}\right)$} & \multicolumn{3}{|c|}{ Activation Energy $(\mathrm{kj} / \mathrm{mol})$} \\
\hline & \multirow{3}{*}{$\begin{array}{c}\text { Aqueous } \\
\text { Obtained Reported } \\
\text { (41) }\end{array}$} & \multirow{3}{*}{\multicolumn{2}{|c|}{$\begin{array}{c}\mathrm{U}+\mathrm{Zr} \\
\text { Obtained Reported }\end{array}$}} & & & eported \\
\hline & & & & $\mathrm{Ob}$ & ained & $(41)$ \\
\hline & & & & Aqueous & $\mathrm{U}+\mathrm{Zr}$ & queous \\
\hline $\mathrm{Cd}$ & 500 & 447 & - & $294 \pm 29.4$ & $315 \pm 31.5$ & 340 \\
\hline
\end{tabular}
stant with repetitive loading of the sample for 80 atomization cycles.

TABLE III

Activation Energies of the Atom Formation for Cd (in aqueous and $\mathrm{U}+\mathrm{Zr}$ ) 
Using freshly optimized parameters with the $U+Z r$ solution, a method was developed for the direct determination of $\mathrm{Cd}$ in a $20 \mathrm{mg} / \mathrm{mL}$ of $\mathrm{U}+20 \% \mathrm{Zr}$ matrix using the $2288 \mathrm{~nm}$ spectral line. Measurements of the atomic absorption signals for Cd were carried out over a wide range of concentrations using standard solutions in these matrices. The linear analytical ranges in the presence and absence of the matrices were obtained. The analytical data on the Cd absorbance in aqueous, $4 \mathrm{mg} / \mathrm{mL} \mathrm{Zr}, 16 \mathrm{mg} / \mathrm{mL} \mathrm{U}$, and $20 \mathrm{mg} / \mathrm{mL}(20 \% \mathrm{Zr} / \mathrm{U}+\mathrm{Zr})$ matrices are shown in Figure 4.

Characteristic concentrations (C.C.), the smallest amount determined and range of the analysis in the presence and absence of the matrix, are given in Table VI. The working linear analytical curves for $4 \mathrm{mg} / \mathrm{mL} \mathrm{Zr}, 16 \mathrm{mg} / \mathrm{mL} \mathrm{U}$, and 20 $\mathrm{mg} / \mathrm{mL}$ (20\%Zr/U+Zr), along with a matrix-free solution, are also shown in the table. As can be seen, the analytical range and sensitivity of the methodology is poorer in a matrix relative to a matrix-free solution.

Peak profiles were plotted at $0.04 \mu \mathrm{g} / \mathrm{mL} \mathrm{Cd}$ in the absence and presence of different matrices ( $4 \mathrm{mg} \mathrm{Zr} / \mathrm{mL}, 16 \mathrm{mg} \mathrm{U} / \mathrm{mL}$, and

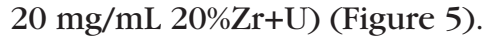
The area, time to reach peak, and width of the different matrices were calculated from the curves and are shown in Table VII. It was observed that the peak profile broadened; peak area reduced in the presence of the matrices as compared to the matrix-free solutions. An increase in peak width can be attributed to a slow analyte release. This indicates that the matrix plays a major role in signal suppression. The stable lattice and closed packed face-centered cubic structure of urania and zirconia acts as an entrapment for the Cd atoms, resulting in the suppression of the Cd absorbance signal in the matrix.

The performance of the above method was evaluated by analyzing synthetic samples containing $\mathrm{Cd}$ in $20 \% \mathrm{Zr}+80 \% \mathrm{U}$. Using the standardized procedure, three synthetic samples were analyzed. The results obtained from the analysis of these synthetic samples are shown in Table VIII. A comparison of these

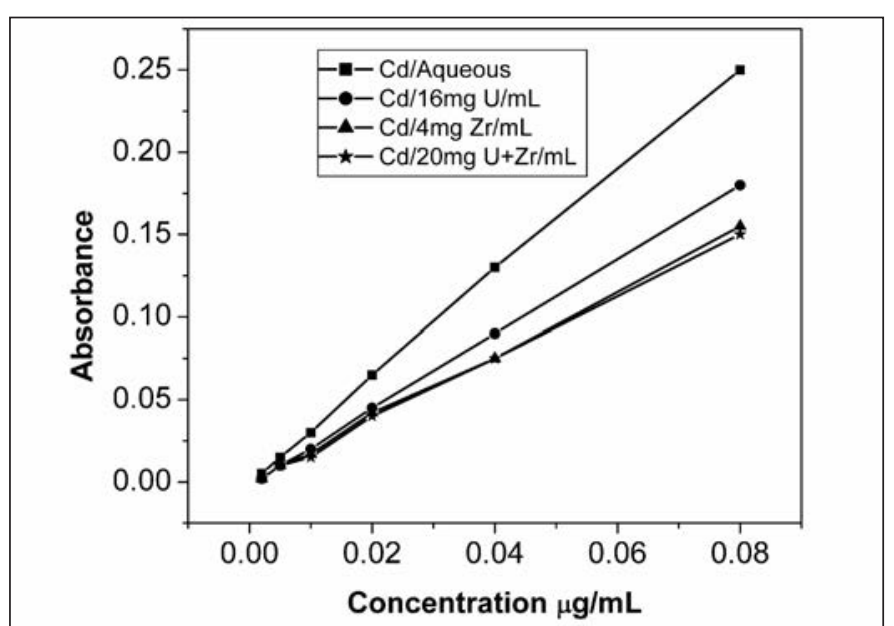

Fig. 4. Analytical curves for Cd in aqueous, $4 \mathrm{mg} / \mathrm{mL} \mathrm{Zr}$, $16 \mathrm{mg} / \mathrm{mL} \mathrm{U}$, and $20 \mathrm{mg} / \mathrm{mL}(20 \% \mathrm{Zr} / \mathrm{U}+\mathrm{Zr})$ matrices.

TABLE IV

Optimization of Experimental Parameters for $\mathrm{Cd}$ at $0.08 \mu \mathrm{g} / \mathrm{mL}$ in U+Zr Matrix With $20 \% \mathrm{Zr}$

\begin{tabular}{lcc|ccc}
\hline \multicolumn{2}{c|}{$\begin{array}{c}\text { Pre-atomization Temperature } \\
\text { for 30 s }\end{array}$} & \multicolumn{3}{c}{$\begin{array}{c}\text { Atomization Temperature } \\
\text { at } 0.3 \mathrm{~s}\end{array}$} \\
\hline $\begin{array}{l}\text { Temp. } \\
\left({ }^{\circ} \mathrm{C}\right)\end{array}$ & $\begin{array}{c}\text { Matrix } \\
\text { Blank }\end{array}$ & $\begin{array}{c}\text { Cd } \\
\text { Signal }\end{array}$ & $\begin{array}{c}\text { Temp. } \\
\left({ }^{\circ} \mathrm{C}\right)\end{array}$ & $\begin{array}{c}\text { Matrix } \\
\text { Blank }\end{array}$ & $\begin{array}{c}\text { Cd } \\
\text { Signal }\end{array}$ \\
\hline 300 & 0.008 & 0.238 & 2100 & 0.008 & 0.193 \\
400 & 0.002 & 0.246 & 2200 & 0.002 & 0.227 \\
500 & 0.002 & 0.251 & 2300 & 0.002 & 0.261 \\
600 & 0.002 & 0.256 & 2400 & 0.004 & 0.260 \\
700 & 0.004 & 0.230 & 2500 & 0.004 & 0.244 \\
\hline
\end{tabular}

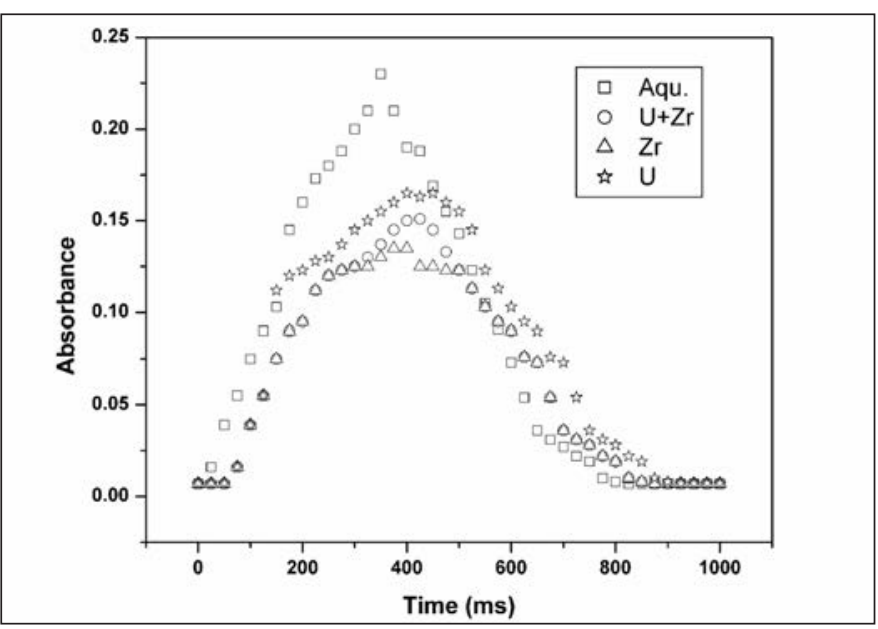

Fig. 5. Peak profiles for $C d$ in aqueous, $U, Z r$, and $U+Z r$ matrices.

TABLE V

Optimized Experimental Parameters of GF for $\mathrm{Cd}$ in $\mathrm{U}+\mathrm{Zr}$

\begin{tabular}{lcrc}
\hline Atomizer & & \multicolumn{2}{c}{ Time $(\mathrm{s})$} \\
Stage & Temp. $\left({ }^{\circ} \mathrm{C}\right)$ & Ramp & Hold \\
\hline Dry & 80 & 5 & 10 \\
& 120 & 10 & 10 \\
& 300 & 5 & 10 \\
Pre-atomize & 500 & 0.2 & 10 \\
Atomize & 2300 & 0.9 & 0.3 \\
Cooling & 20 & 14.5 & 10.0 \\
\hline
\end{tabular}


results based on 8-10 replicate measurements indicates close agreement for all determinations. The replicate analyses of the synthetic samples resulted in the precision of the method to be better than $8 \%$ RSD.

The influence of mixed matrices on the $\mathrm{Cd}$ atomization behavior showed that the Cd sensitivity is poorer in mixed matrices as compared to pure nitrate solutions, but did not change with a change in percentage of $\mathrm{Zr}$. It is, therefore, necessary to match the standard and sample compositions in the mixed matrix. The matrix composition was finalized to $20 \% \mathrm{Zr} /(\mathrm{U}+\mathrm{Zr})$ for further studies. The range of analysis was found to be $0.005-0.08 \mu \mathrm{g} / \mathrm{mL}$ for Cd with a $20 \mathrm{mg} / \mathrm{mL}$ matrix, which results in detection limits of $0.25 \mathrm{ppm}$.

It is possible to determine $\mathrm{Cd}$ in a $\mathrm{Zr}+\mathrm{U}$ matrix successfully using the optimized methods. In view of the high detection limits obtained for the analyte in a uranium-zirconium matrix, the method is not meeting the specification limits required for the analyte in FBR fuels. The poor atomization efficiency in the presence of $\mathrm{U}+\mathrm{Zr}$ is correlated with the entrapment of the analytes in the stable lattices of urania and zirconia in addition to a release of oxygen in a uranium matrix. Further studies were, therefore, conducted from uranium + zirconium separated and pre-concentrated solutions using GFAAS.

\section{Separation Procedure}

The specification limit for $\mathrm{Cd}$ in $\mathrm{Zr}+\mathrm{U}$ is at $0.1 \mathrm{ppm}$ level. To achieve the desired low detection limits at the $0.1 \mathrm{ppm}$ level for $\mathrm{Cd}$, an alternate method was developed which involved chemical separation of the matrix and analysis of the raffinate using GFAAS. Chemical separation procedures based on solvent extraction/ion exchange can be used for this purpose; however, the former procedure, being faster, is preferred. Since quantitative chemical separation of the analyte is most essential, detailed studies were carried out to select

\section{Atomic Spectroscopy 1 Vol. 35(4), July/August 2014}

proper extractants, diluent, and aqueous medium which would facilitate the same. Solvent extraction procedures have been developed using different extractants for the analysis of common metals in $\mathrm{U}+\mathrm{Zr}$ bearing fuel samples (43) and in $\mathrm{U}-\mathrm{Pu}-\mathrm{Zr}$ (32). However, in the present studies, the methods used are $30 \% \mathrm{TBP} / \mathrm{CCl}_{4}$ in $7 \mathrm{M} \mathrm{HNO}_{3}$ (44) for the separation of the matrix and for analysis. It was reported (44) that with $30 \% \mathrm{TBP}+70 \% \mathrm{CCl}_{4}$ in $7 \mathrm{M}$ $\mathrm{HNO}_{3}$, a selective simultaneous extraction of $\mathrm{U}$ and $\mathrm{Zr}$ into the organic phase can be achieved. In the present studies, the same extraction procedure was applied using $100 \mathrm{mg} \mathrm{U}+\mathrm{Zr}$. The effect of $\mathrm{U}+\mathrm{Zr}$ in the raffinate on $\mathrm{Cd}$ was also estimated.

It was reported (44) that during separation of $1 \mathrm{~g} \mathrm{Zr+U}$, the raffinate contains analytes and a small amount of matrix. The matrix concentration in the raffinate was in the range of $\sim 10-50 \mu \mathrm{g} / \mathrm{mL}$. Therefore, to utilize the separated method for the determination of

TABLE VI

Characteristic Concentrations (C.C.), the Smallest Amount Determined and Range of Analysis

\begin{tabular}{|c|c|c|c|c|c|}
\hline \multirow[t]{2}{*}{ Matrix } & \multirow{2}{*}{$\begin{array}{c}\text { C. C. } \\
(\mathrm{ng} / \mathrm{mL})\end{array}$} & \multicolumn{2}{|c|}{ Linear Analytical Range } & \multicolumn{2}{|c|}{ LOQ (g) } \\
\hline & & $(\mu \mathrm{g} / \mathrm{mL})$ & $\begin{array}{r}(\mathrm{ppm}) \\
(\mu \mathrm{g} / \mathrm{g})\end{array}$ & Present & $\begin{array}{l}\text { Reported } \\
\text { (37) }\end{array}$ \\
\hline Aqueous & 0.2 & $0.002-0.08$ & - & $1.0 \times 10^{-11}$ & $0.5 \times 10^{-12}$ \\
\hline $4 \mathrm{mg} / \mathrm{mL} \mathrm{Zr}$ & 0.25 & $0.005-0.08$ & $1.25-20.0^{\mathrm{a}}$ & $2.0 \times 10^{-11}$ & - \\
\hline $16 \mathrm{mg} / \mathrm{mL} \mathrm{U}$ & 0.35 & $0.005-0.08$ & $0.3125-5.0^{\mathrm{b}}$ & $2.0 \times 10^{-11}$ & - \\
\hline $20 \mathrm{mg} / \mathrm{mL} \mathrm{U}+\mathrm{Zr}$ & 0.3 & $0.005-0.08$ & $0.25-4.0^{c}$ & $2.0 \times 10^{-11}$ & - \\
\hline
\end{tabular}

${ }^{\mathrm{a}}$ Based on $20 \mu \mathrm{g}$ of $\mathrm{Zr},{ }^{\mathrm{b}}$ Based on $80 \mu \mathrm{g}$ of $\mathrm{U},{ }^{\mathrm{c}}$ Based on $100 \mu \mathrm{g}(\mathrm{Zr} / \mathrm{U}+\mathrm{Zr})$ in $5 \mu \mathrm{L}$ of solution.

TABLE VII

Calculated Profiles of Area of Different Matrices, Time to Reach Peak, Width, and Height

\begin{tabular}{cllcc}
\hline Sample & Matrix & Area & Peak at $(\mathrm{ms})$ & Width \\
\hline 1 & Matrix-free & 89.35 & 350 & 375 \\
2 & $16 \mathrm{mg} / \mathrm{mL} \mathrm{U}$ & 81.65 & 400 & 521 \\
3 & $20 \mathrm{mg} / \mathrm{mL} \mathrm{U}+\mathrm{Zr}$ & 69.45 & 425 & 475 \\
4 & $4 \mathrm{mg} / \mathrm{mL} \mathrm{Zr}$ & 67.125 & 375 & 525 \\
\hline
\end{tabular}

TABLE VIII

Results of Analysis of Three Synthetically Prepared Samples for the Determination of $\mathrm{Cd}$ at $\mathrm{ppm}$

\begin{tabular}{ccccc}
\hline Sample & Concentration of Spike (ppm) & (\%) RSD \\
\hline \multicolumn{5}{c}{ Added } \\
1 & 0.8 & 0.77 & 0.775 & 8 \\
2 & 1.5 & 1.51 & 1.45 & 7 \\
3 & 2.5 & 2.34 & 2.35 & 4 \\
\hline
\end{tabular}


$\mathrm{Cd}$, it is important to understand the effect of $10-50 \mu \mathrm{g} / \mathrm{mL} \mathrm{Zr}+\mathrm{U}$ in the raffinate on $\mathrm{Cd}$. The effect of $20 \% \mathrm{Zr} / \mathrm{Zr}+\mathrm{U}$ on $\mathrm{Cd}$ was also studied at the concentration of $0.04 \mu \mathrm{g} / \mathrm{mL}$. It was observed that the $\mathrm{Cd}$ absorbance remained unaffected with an increase in matrix concentration in the range of $10-50 \mu \mathrm{g} / \mathrm{mL}$. In order to achieve the desired detection limit of $0.1 \mathrm{ppm}$ for the element, a method was developed using U+Zr samples after chemical separation with 30\% TBP/dodecane in $7 \mathrm{M} \mathrm{HNO}_{3}$. Four times the chemical separation was applied using $30 \% \mathrm{TBP} /$ dodecane in $7 \mathrm{M} \mathrm{HNO}_{3}$ for the near total removal of the matrix. The detection limits obtained with this method were $0.1 \mathrm{ppm}$ for Cd.

The results of the aqueous samples obtained with the GBC-906 GFAAS were also validated using the SPECTRO ARCOS SOP ICP-AES independently. However, ICP-AES suffers from severe spectral interference in the presence of $\mathrm{Zr}$ (44) and $U$ (45) matrices with line-rich emission spectra and hence, the samples were analyzed only in aqueous solutions. However, it was found that the Cd estimations by ICP-AES were not affected in the presence of $10-50 \mu \mathrm{g} / \mathrm{mL} \mathrm{U}+\mathrm{Zr}$ as well. The results of the analysis of the synthetic samples with varying concentrations of matrix and a real sample analyzed using the GBC-906 GFAAS and SPECTRO ARCOS SOP ICP-AES are shown in Table IX .

\section{CONCLUSION}

These studies showed that the Cd absorbance signal kept decreasing with an increase in matrix concentration ranging from $0-40$ $\mathrm{mg} / \mathrm{mL}$ of $\mathrm{U}+\mathrm{Zr}$. Attempts were made to understand the effect of $\mathrm{Zr}+\mathrm{U}$ on analyte absorbance and the reaction involved in the atomization of the analyte in the matrix. The matrix concentration was optimized to $20 \mathrm{mg} / \mathrm{mL}$. To use the

TABLE IX

Analysis of Synthetic Samples With Varying Concentrations of Matrix and a Real Sample Obtained With the GBC-906 GFAAS and SPECTRO ARCOS SOP ICP-AES

\begin{tabular}{|c|c|c|c|c|c|}
\hline \multirow{3}{*}{$\begin{array}{l}\text { Sample } \\
\text { No. }\end{array}$} & \multirow{3}{*}{$\begin{array}{l}\text { Expected } \\
\text { Cd }\end{array}$} & \multicolumn{4}{|c|}{ Concentration of Spike $(\mu \mathrm{g} / \mathrm{mL})$} \\
\hline & & \multicolumn{2}{|c|}{ GFAAS } & \multicolumn{2}{|c|}{ ICP-AES } \\
\hline & & Obtained & (\%) RSD & Obtained & (\%) RSD \\
\hline 1. & 0.05 matrix-free & 0.05 & 5 & 0.051 & $<5$ \\
\hline 2. & $0.05+10 \mu \mathrm{g} / \mathrm{mL}$ matrix & 0.054 & 7 & 0.055 & $<5$ \\
\hline 3. & $0.05+20 \mu \mathrm{g} / \mathrm{mL}$ matrix & 0.049 & 6 & 0.056 & $<5$ \\
\hline 4. & $0.05+50 \mu \mathrm{g} / \mathrm{mL}$ matrix & 0.05 & 5 & 0.06 & $<5$ \\
\hline 5. & 0.05 real sample & 0.054 & 5 & 0.056 & $<5$ \\
\hline 6. & 0.1 matrix-free & 0.1 & 5 & 0.1 & $<5$ \\
\hline 7. & $0.1+10 \mu \mathrm{g} / \mathrm{mL}$ & 0.11 & 7 & 0.107 & $<5$ \\
\hline 8. & $0.1+20 \mu \mathrm{g} / \mathrm{mL}$ matrix & 0.105 & 6 & 0.106 & $<5$ \\
\hline 9. & $0.1+50 \mu \mathrm{g} / \mathrm{mL}$ matrix & 0.098 & 5 & 0.11 & $<5$ \\
\hline 10. & 0.1 real sample & 0.1 & 5 & 0.11 & $<5$ \\
\hline
\end{tabular}

method for uranium-zirconium mixed oxide samples, the effects of varying concentrations of $\mathrm{Zr}$ in a $\mathrm{Zr}+\mathrm{U}$ mixed matrix were studied. The results indicated that the absorbance signal remained unaffected in the range of $0-40 \% \mathrm{Zr}$ in a $(\mathrm{Zr}+\mathrm{U})$ mixed matrix with $20 \mathrm{mg} / \mathrm{mL}$ total matrix. Cd can be determined by GFAAS in $20 \% \mathrm{Zr} / \mathrm{Zr}+\mathrm{U}$ samples in the range of $0.005-0.08 \mu \mathrm{g} / \mathrm{mL}$, which leads to $0.25 \mathrm{ppm}$ on a $20 \mathrm{mg} / \mathrm{mL}$ sample basis. Though the method is not suitable to determine Cd directly in fast breeder reactor (FBR) fuels due to stringent specification limits, matrix separation by the chemical method enables GFAAS to estimate $\mathrm{Cd}$ at the required level of $0.1 \mathrm{ppm}$ using the raffinate containing a matrix of $50 \mu \mathrm{g} / \mathrm{mL}$ of matrix.

\section{ACKNOWLEDGMENT}

The authors are grateful to Dr. Ashok Goswami, Head, Radiochemistry Division, for his keen interest and constant encouragement in the course of this work.

Received February 13, 2014.

\section{REFERENCES}

1. D. Prat, R. Compano, M. Granados and E. Miralles, J. Chromatogr. A 746, 239(1996).

2. Neelam Goyal, P.J. Purohit and S.V. Godbole, At. Spectrosc. 31(6) 190 (2010).

3. B. Rajeshwari, B.A.Dhawale, T.K.Seshagiri, P.J.Purohit, Neelam Goyal and A.G.Page, J. of the Indian Chemical Society 83, 1 (2006).

4. Santosh Kumar Gupta, S.K. Thulasidas, Neelam Goyal, and S.V. Godbole, Instrumentation Science \& Technology 42(2), 161 (2014).

5. B.M. Patel, P.M. Bhatt, Neelam Gupta, M.M.Pawar and B.D. Joshi, Anal. Chim. Acta.104, 113 (1979).

6. Neelam Goyal, P.J. Purohit, A.R. Dhobale, B.M. Patel, A.G. Page and M.D. Sastry, J. Anal. At. Spectrom. 2, 459 (1987).

7. P.J. Purohit, Neelam Goyal and S.V. Godbole, At. Spectrosc. 33, 100 (2012).

8. S. Kinaree and S. Chanthai, Chemical Papers 68(3), 342 (2014).

9. G. Hou, Y. Li, Y. Cheng, Anal. Lett. 46, 1978 (2013). 
10. S. Bakirdere, T. Yaroglu, N. Tirik, M. Demiröz, A. K. Fidan, O. Maruldali, and A. Karaca, J. of Spectrosc. 1(1), art. no. 824817 (2013).

11. H. Matsumiya, T. Kato, and M. Hiraide, Talanta 119, 505 (2014).

12. A. Chahid, M. Hilali, A. Benlhachimi, and T. Bouzid, Food Chem. 147, 357 (2014).

13. A.M Hernández-Martínez and C. Padrón-Sanz, Anal. Methods 5, 6473 (2013).

14. A.A. Shaltout, M. S. Abdel-Aal, B. Welz, and I. N. B.Castilho; Anal. Lett. 46, 2089 (2013).

15. M. Acosta, M. Savio, M. C. Talio, M.L. Ferramola, R. A, Gil, and L. D. Martinez, Microchem. Journal 110, 94 (2013).

16 S. Sounderajan, G. K. Kumar, A. C. Udas, and T. Mukherjee, At. Spectrosc. 34, 181 (2013).

17. M.H. Givianrad, H. Ezzatpanah, and M. Chitsazi, Asian J. of Chem. 25, 4685 (2013).

18. S. Antakli, N. Sarkis, and A. A. Hajar, Asian J. of Chem. 24 (6), 2613 (2012).

19. L.-J. Du, H.-M Yan, J.-L. Shao, J.-L. Fan, J.-Y. Chen, S.-S. Lan and L.-Z. He, Modern Food Science and Technol. 29(2), 426,(2013).

20. N.B. Ivanenko, N.D. Solovyev, A.A. Ivanenko, and A.A. Ganeev, Archives of Environ. Contamination and Toxicology 63, 299 (2012).

21. T. Ren, L.-J. Zhao, J. Cao, R.-G. Zhong, Pu Xue Yu Guang and Pu Fen Xi Guang, Spectroscopy and Spectral Analysis 32, 2566 (2012).

22. V. Nour, I. Trandafir, and M. E. Ionica, J. of Environ. Protection and Ecology 12, 2046, (2011).

23. M.B. Dessuy, M.G.R. Vale, B. Welz, A.R. Borges, M.M. Silva, and P. B. Martelli, Talanta 85, 681 (2011).

24. Determination of cadmium in biological samples: An update from 2006 to 2011, P. Wu, C. Li, J. Chen, C. Zheng, and X. Hou, Applied Spectrosc. Reviews 47(5), 327 (2012).
25. A. P. de Oliveira, R. D. Villa, D. Goveia, F. A. Lobo, and A. H. Rosa, Current Anal. Chem. 7(3), 220 (2011).

26. J. Sardans, F. Montes and J. Peñuelas, Soil and Sediment Contamination 20 (4), 447 (2011).

27. P. Török and M. Žemberyová, Spectrochim. Acta - Part B, At. Spectrosc. 66, 93 (2011).

28. S. Abbasi, K. Khodarahmiyan, and F. Abbasi, Food Chemistry 128 (1), 254 (2011).

29. Y. Fukui, F. Ohashi, S. Sakuragi, J. Moriguchi, and M. Ikeda, Industrial Health 49(3), 338 (2011).

30. M. Salahinejad and F. Aflaki, Environmental Monitoring and Assessment 177 (1-4), 115 (2011).

31. X. Guo,M. He, B. Chen, and B. Hu, Talanta 101, 516 (2012).

32. E.A. Huff and S.J. Kulpa, Anal. Chem. 38(7), 939 (1966).

33. Santosh Kumar Gupta, S.K. Thulasidas, P.J. Purohit, Neelam Goyal and S. V. Godbole, At. Spectrosc. 35, 43 (2014).

34. Santosh Kumar Gupta, Neelam Goyal, and S.V. Godbole, At. Spectrosc.32,107 (2011).

35. Santosh Kumar Gupta, S.K. Thulasidas, Neelam Goyal, and S.V. Godbole, At. Spectrosc. 34, 104, (2013).

36. Paru J. Purohit, Neelam Goyal and S.V. Godbole, At. Spectrosc. 32, 68 (2011).

37. Neelam Goyal, Renu Agarwal, Paru J. Purohit and S. V. Godbole, J. of Nucl. Materials, 376, 119 (2008).

38. CRC Handbook of Chemistry and Physics, Ed. By R. C. Weast, published by Chemical Rubber Company, Ohio, USA. (1971-72).

39. Neelam Goyal, P.J. Purohit, A.R. Dhobale ,B.M. Patel, A.G. Page and M.D. Sastr, J. Anal. At. Spectrom. 2, 459 (1987).

40. Direct Determination of $\mathrm{Ag}$ in $\mathrm{Zr}$ Matrix by ETA-AAS, P.J. Purohit, Neelam Goyal, A.G. Page and M.D. Sastry, Indian Council of Chemists, held at Goa during Oct. 1991, pp. 202 (1991).

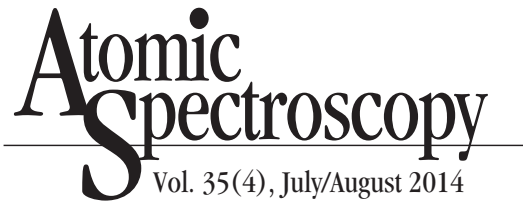

41. R.E. Sturgeon and C.L. Chakraborty, Prog. in Anal. At. Spectrosc. 1 (1978) 147.

42. C. Duval, Inorganic Thermogravimetric Analysis, Elsevier, New York, USA, pp. 666 (1963).

43. K. Satyanarayana and S. Durani, J. Radioanal. and Nucl. Chem. 285, 659, (2010).

44. Arijit Sengupta, B. Rajeshwari, R.M. Kadam, and S.V. Godbole, At. Spectrosc. 33(2), 48 (2012).

45. M. Kumar, M. Mohapatra, Paru J. Purohit, S. K. Thulasidas, T. Seshagiri, Neelam Goyal and S. V. Godbole, At. Spectrosc. 31(3), 97 (2010). 